\title{
Lean budget leaves scientists wanting more
}

\section{Geoff Brumfiel and}

Tony Reichhardt, Washington

US science agencies will face a financial squeeze in 2005. The federal budget, passed by Congress on 20 November, provides little new money for research and imposes cuts on several agencies.

The Department of Homeland Security and the Pentagon are the only clear winners (see chart) - both receive a big increase to develop technologies to combat terrorism. The National Institutes of Health gets a mere $2 \%$ increase to $\$ 28.6$ billion, well below the $15 \%$ increases it received annually between 1998 and 2003. Faring slightly better is the Department of Energy's science office, which sees a $2.8 \%$ increase to $\$ 3.6$ billion. On the losing side is the Environmental Protection Agency, whose research budget falls $4.8 \%$ to $\$ 744$ million.

But the National Science Foundation (NSF) was by far the most disappointed — its budget will drop $1.9 \%$ to $\$ 5.5$ billion next year. The decline, the agency's first since 1990 , comes after several years of strong increases that science lobbyists had hoped would lead to a doubling of the foundation's budget. "I think various science coalitions are trying to scale down their expectations," says Nadine Lymn, director of public affairs at the Ecological Society of America in Washington.

The NSF budget cuts result in part from

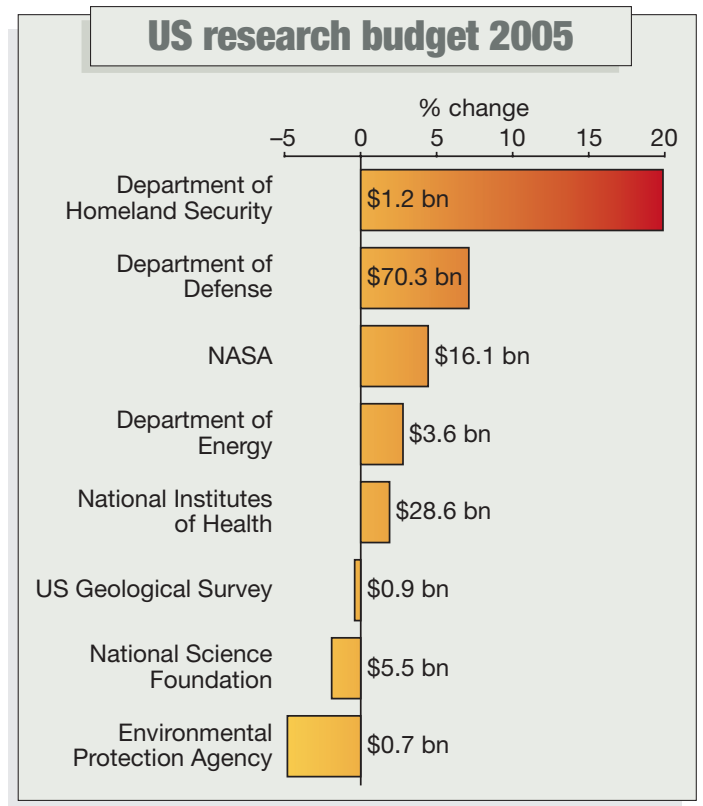

programme: a manned space vehicle that is expected to make a test flight in 2008.

Lubell sharply criticizes the decision to fund what he describes as a politically initiated project at the expense of peerreviewed programmes at the NSF. And on 22 November, the American Physical Society issued a report warning that important projects could be delayed or cancelled as NASA prioritizes the Moon-Mars mission. "No one has laid out what the scientific benefits of this mission are going to be," says Lubell.

Funding for a few specific science programmes is also significantly reduced. Most notably, a White House miscalculation led Congress to assign just $\$ 577$ million to the construction of a nuclear-waste repository in Yucca Mountain, Nevada, well below the $\$ 880$ million requested for the project for 2005 (see Nature 430, 820; 2004).

Kei Koizumi, who directs the budget President George W. Bush's plan to send astronauts to the Moon and eventually to Mars, says Michael Lubell, director of public affairs for the American Physical Society in Washington. That plan moved closer to reality last week, as NASA was granted its full request of $\$ 16.1$ billion, up $4.5 \%$ from last year. The funding should allow NASA to stay on schedule and pick contractors in August to build the first major piece of hardware for this and policy programme at the American Association for the Advancement of Science in Washington, says tight years lie ahead for federal science agencies. The Bush administration is committed to halving the budget deficit by 2009 , but it is still running up debt owing to recent tax cuts and military action in Iraq. "There's a lot of spending going on," Koizumi says, so the money must come from cuts to domestic programmes, such as science.

\section{$\mathrm{NIH}$ head stands firm over plans for open access}

Meredith Wadman, Washington

The director of the US National Institutes of Health (NIH) has hit back at critics of his proposal for a freely accessible literature archive.

In an interview with Nature, Elias Zerhouni accused scientific publishers of floating "doomsday scenarios" in which the archive causes widespread cancellations of journal subscriptions and drives smaller publications out of business. He stressed that submission of papers on NIH-funded research would be left to the discretion of authors. But publishers rejected his assurances, saying that researchers would feel pressured to submit their papers for fear of losing out on future NIH grants.

Zerhouni's comments came on 16 November, at the end of a 60-day public discussion period that generated more than 6,000 comments on the proposal (see Nature $431,115 ; 2004)$. The policy calls for all papers produced with NIH funding to be submitted electronically to the agency after completing peer review. Six months after publication, the papers would appear in PubMed Central, the NIH's online public archive.

Many scientific publishers oppose the proposal, saying that offering their articles for free could drive journals out of business. They add that inaccuracies will be preserved in PubMed, because the policy proposes that articles be posted before copyediting and correcting. But patient-activist groups and librarians have been vocally supportive. They argue that the archive would improve public education, communication between scientists and the translation of biomedical advances into healthcare.

Zerhouni last week dismissed some of the publishers' fears, accusing them of releasing "misinformation" about the impact on subscriptions. He added that researchers would be free to opt out of the archive. "I'm willing to take the risk of seeing the decision made not by government fiat but by the scientists themselves," he said. "If they don't wish to publish on the NIH website, that's their decision and the decision of their publishers, not mine."

Publishers say that the argument is disingenuous. They point out that the policy requires authors and not journals to submit papers. "Researchers would that if they did not comply with this plan, they might be looked upon with less favour for awards of future NIH grants," says Allan Adler, a lobbyist with the Association of American Publishers.

The NIH is scheduled to submit a final version of the policy to Congress by 1 December, but Zerhouni says that the flood of comments makes it almost certain that this deadline will slip. 